\title{
Prospects of wind power generation in Jordan: the case of street lighting
}

\author{
S. Sawalha
}

\begin{abstract}
The main objective of the current study is to examine and analyze technical and economic issues affecting of the use of wind energy utilization in street lighting in Jordan.

As per the Meteorological Department of Jordan the minimum wind speed is $7 \mathrm{~m} / \mathrm{s}$ in Jordan which is above the global average. Technically it's fond that using a horizontal turbine with three blades is enough to produce the necessary energy for street lighting.

Taking into consideration the cost of the turbine and pole lighting and bulbs, operation and maintenance, it's found that the recovery of the cost of the system need about 12 year at wind speed $7 \mathrm{~m} / \mathrm{s}$, thus, there is economic benefit equivalent of $\$ 1700$.
\end{abstract}

\section{Key words}

Wind energy, street lighting, renewable energy, electricity generation, Jordan

\section{Introduction}

Jordan suffers from a sever lack in energy resources, at the same time the energy consumption in Jordan is increasing yearly as it has reached $6.15 \%$ of the GDP at the end of 2015, which creates an economic burden on the GDP and imposes a necessity for detailed search for alternative sources of energy.

Total Jordan's imports of energy constitute about 1,603 Billion JD (2.258 Billion US Dollar) in 2015 (Tab. 1), about $96 \%$ of these needs from abroad, according to the World Bank report, which is so much relative to the Jordanian national product (Note that the Jordanian national product is equivalent to 0.00037 of global GDP for the same year [1].

The increasing value of the oil bill in Jordan is linked to number of internal and external factors, including:

1. The rate of population growth, which is considered high (about 2.2\%) [2].

2.Increasing in the total number of operating vehicles (1,336, 667 vehicle) in 2015 [3].

Table (1): The Jordan energy bill.

\begin{tabular}{|l|c|c|}
\hline $\begin{array}{l}\text { Type of petroleum } \\
\text { material }\end{array}$ & $\begin{array}{l}\text { Value of imports, } \\
\text { million JD }\end{array}$ & $\begin{array}{l}\text { Percent of the total } \\
\text { energy imports }\end{array}$ \\
\hline Crude oil & 886.78 & $\% 28.6$ \\
\hline Diesel & 529.53 & $\% 16.6$ \\
\hline Fuel oil & 289.58 & $\% 0.0$ \\
\hline
\end{tabular}

\begin{tabular}{|l|c|c|}
\hline & & \\
\hline Lubricant & 22.92 & $\% 3.7$ \\
\hline Petroleum gases & 218.92 & $\% 34.7$ \\
\hline Gasoline & 222.76 & $\% 15.4$ \\
\hline Natural gas & 47.54 & $\% 0.0$ \\
\hline Electricity & 40.07 & $\% 1.0$ \\
\hline Total & 2258 & $\% 100$ \\
\hline
\end{tabular}

3. Increased demand for $\mathrm{A} / \mathrm{C}$ devices due to high temperatures resulting from climate change, which reached two degrees Celsius.

4. Jordan constitutes asylum to the refuges from neighboring Arab countries suffering from wars (Iraq and Syria). This issue contributed to increased energy consumption about 3\% (equivalent 7.25 million US Dollars of the Jordan's energy bill) in 2011-2012 [4]. In the past few years, the Jordanian Government went towards diversifying energy taking into consideration the above-mentioned circumstances, namely toward the solar and wind energy, to ensure economic stability. Jordan has a countless source of wind and solar energy, provides an opportunity for the country to reduce both energy costs and reliance on hydrocarbons without burdening the budget. Jordan comes in the forefront countries in the Middle East Region in mobilizing private capital towards investment in the field of renewable energy. Since 2012 the private sector built nine solar power plants and one wind power plant to generate electricity.

In this context, the friendly countries to Jordan encourage and contribute to the provision of financial and technical support for the success of the Jordanian Government directed towards alternative energy as part of the main solution to economic problems.

The European Central Bank began to reconstruct, develop, and support renewable energy programs in Jordan since 2012, which included the financing of solar photovoltaic power plants with a capacity of $60 \mathrm{MW}$. In addition to a70-million-dollar loan for Green Watts LLC, to build a wind power plant with a capacity of $86 \mathrm{MW}$ [5]. 


\section{Wind energy theory}

Wind power is extracted from wind energy for further a applications of energy, such as wind turbines to produce electricity and wind mills to generate mechanical power. wind turbine is a device which converts wind kinetic energy into mechanical energy. In case of electricity is the output of such energy then it is called wind generator or wind charger. Wind turbines are manufactured in a range scale of vertical and horizontal axis types. The smallest are used for limited applications such as battery charging or auxiliary power on sailing boats. whereas, large turbines are used increasingly as a major source of commercial electric power.

Even though the nature of the wind is discontinuous, wind patterns at particular places remain almost constant throughout the years. The average wind speed in hilly and coastal areas, is greater than at inland. This is probably because the wind tends to blow consistent pattern over the surface of the water. Moreover, wind speed increases with elevations. At $60 \mathrm{~m}$ elevation, the wind speed range is $30-$ $60 \%$ greater than low altitude lands. Accordingly, wind blades are preferred to be installed at heights so that the maximum amount of wind leading continuous rotation.

Wind energy conversion systems classification mainly is based on different orientation as elaborated hereafter:

1. Axis of rotation

2. Output power

a) DC Output

b) DC generator

c) Alternator rectifier

d) AC Output

e) Variable or constant frequency

3. Rotational speed

a) Constant speed Vs. variable pitch blades

b) Constant speed Vs. fixed pitch blades

c) Variable speed Vs. fixed pitch blades

4. Output utilization

a) Battery storage

b) Direct connection to an electromagnetic energy convertor

c) Other form of storage

d) Inter connection with conventional electricity utility grids.

However, there are three basic factors influence the output of wind energy conversion system, viz:

a) Wind speed

b) Cross section of the windswept by the rotor.

c) Conversion efficiency of the rotor, transmission system generator or pump.

From Theoretical point of view, it may be impossible to obtain $100 \%$ efficiency through halting and preventing the passage of air through the rotor. However, no certain equipment can eliminate all the wind energy but only able to slow down the air column to one third of its free velocity. achieving $100 \%$ efficient wind generator can convert maximum up to $60 \%$ of available wind energy into mechanical energy. Moreover, such losses sustained in the generator or pump decreases the inclusive efficiency of power generation to $35 \%$ [6]. Figure 1 shows the general block diagram of the wind energy conversion system (WECS).

a) Horizontal axis machines

b) Vertical axis machines

5. Size if machine

a) Minor scale (up to $2 \mathrm{KW}$ )

b) Intermediate scale (2-100 KW)

c) Great scale (100 KW and up)

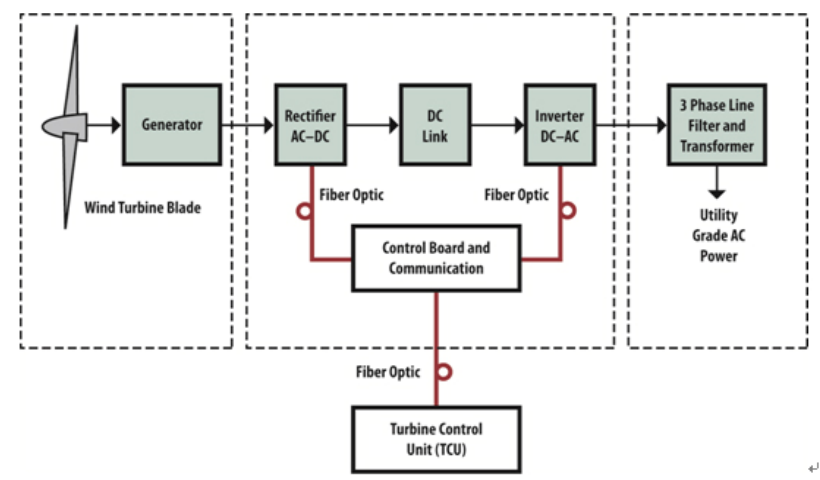

Figure (1): Block diagram of components of a wind energy conversion system [6].

The wind-electrical generating power plant with its components is shown in figure (2).

In order to best utilization wind power emerged what is known as onshore and offshore wind farms in some countries (Table 2 and 3).

The wind ranch comprises of several wind turbines located nearby at one place in order to produce electricity. Large wind ranch may consist of several hundreds of individual wind distributed on an extended area of turbines, yet the spacing between the turbines can effectively be used for farming or other purposes [7].

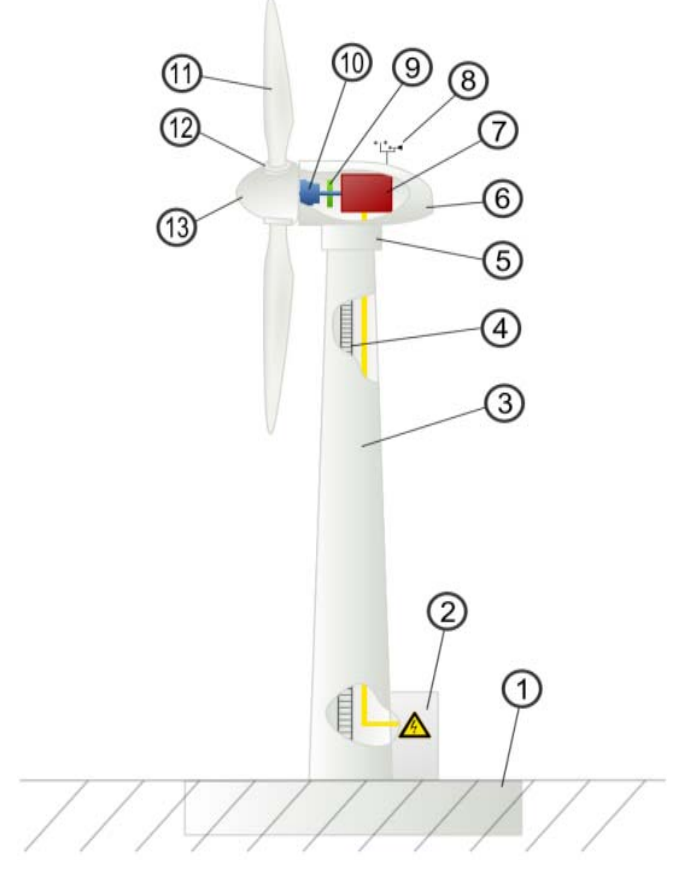

Figure (2): Typical wind turbine components [6]. 1-Foundation, 2-Connection to the electric grid, 3-Tower, 4-Access ladder, 5Wind orientation control (Yaw control), 6-Nacelle, 7-Generator, 8-Anemometer, 9-Electric or Mechanical Brake, 10-Gearbox, 11-Rotor blade, 12-Blade pitch control, 13-Rotor hub. 
Table (2): Onshore wind farm

\begin{tabular}{|l|c|l|}
\hline $\begin{array}{l}\text { Name of the } \\
\text { wind farm }\end{array}$ & $\begin{array}{c}\text { Production (M } \\
\text { watt) }\end{array}$ & Country \\
\hline Gansu & 6,000 & China \\
\hline Alta & 1,320 & USA \\
\hline Jaisalmer & 1,064 & USA \\
\hline Shepherds Flat & 845 & USA \\
\hline Roscoe & 782 & USA \\
\hline Horse Hollow & 736 & USA \\
\hline Capricorn Ridge & 662 & Romania \\
\hline $\begin{array}{l}\text { Ventnalh- } \\
\text { Cogealac }\end{array}$ & 600 & USA \\
\hline Fowler Ridge & 600 & U US \\
\hline Whitley & 539 & U \\
\hline
\end{tabular}

\section{Wind turbine Design and calculation}

When comparing the characteristics and features of the horizontal and vertical turbine, it is found that the horizontal turbines are best suited for use in street lighting $[8,9,10,11]$.

Commercial wind turbines are built with a propeller-type rotor on a horizontal axis (i.e., a horizontal main shaft). Most horizontal axis turbines built are two or three bladed, although some have fewer or more blades.

Table (3): Offshore wind ranch.

\begin{tabular}{|l|l|l|l|l|}
\hline $\begin{array}{l}\text { Name } \\
\text { of the } \\
\text { wind } \\
\text { farm }\end{array}$ & $\begin{array}{l}\text { Power, } \\
\text { Mwatt }\end{array}$ & Country & Turbine Type & $\begin{array}{l}\text { Date of } \\
\text { operation }\end{array}$ \\
\hline $\begin{array}{l}\text { London } \\
\text { Array }\end{array}$ & 630 & $\begin{array}{l}\text { UK } \\
175 \times \text { SWT-3.6 }\end{array}$ & 2012 \\
\hline $\begin{array}{l}\text { Greater } \\
\text { Gabbard }\end{array}$ & 504 & Eank & $140 \times$ SWT-3.6 & 2012 \\
\hline Aanholt & 400 & Denmark & $\begin{array}{l}111 \times \text { SWT- } \\
3.6-120\end{array}$ & 2013 \\
\hline Bard 1 & 400 & Germany & $\begin{array}{l}80 \\
\text { Turbine5.0Bard }\end{array}$ & 2013 \\
\hline
\end{tabular}

The rewards of horizontal axis wind turbines are:

1. Sites, every 10 meters up the wind speed can increase by $20 \%$ and the power output by $34 \%$.

2. Two-high efficiency, since the blades always moves perpendicularly to the wind, receiving power through the whole rotation. In contrast, all vertical axis wind turbines, and most proposed airborne wind turbine designs, involve various types of responding actions, requiring airfoil for part of the cycle. Backtracking against the wind leads to inherently lower efficiency.

3. Variable pitch is possible by which the angle of attack of the turbine blades can be controlled.

4. The blades always move perpendicular to the wind. This leads to higher efficiency as the blades receive power throughout the revolution.

Hindrances of horizontal axis wind turbines are:

1. The tall towers of the HAWT are difficult to transport and install, this problem solve with lamp column.

2. The downwind HAWT suffers from fatigue.

3. The large HAWTs require additional yaw control systems to point them into the wind.

4. The tall tower base allows access to stronger wind in sites with wind shear. In some wind shear Rotations of blades result in cyclic stresses and vibrations in the main bearings of the turbine.

It found that street lighting need a minimum power of 120 watts, so to produce this amount from the power wind relation: An ideal wind turbine has a maximum power coefficient of $16 / 27$. The theoretical limit cannot be exceeded and this caused by the aerodynamic losses due to conversion of angular momentum, tip and drag [12]. The calculation results are shown in table 4.

\section{4- Economical feasibility}

To find out the result of using wind energy in street lighting were identified cost-effectiveness compared with the costs of lighting currently used by the Jordanian electricity company- NEPCO (90 US Dollar per year) as a supplier of electric power for this purpose.

Taking into account the turbine cost, installation of lighting pillar, and the costs of operation and maintenance a humble economic feasibility study was conducted at different wind speed, for instance, 5 -14 $\mathrm{m} / \mathrm{s}$. The cash flow results are given in table 5 . 
Table (4): The calculation results.

\begin{tabular}{|c|c|c|c|c|c|c|c|}
\hline $\begin{array}{l}\text { wind } \\
\text { speed } \\
\text { "m/s" }\end{array}$ & $\begin{array}{c}\text { power wind } \\
\text { "W" }\end{array}$ & $\begin{array}{c}\text { power } \\
\text { mechanical } \\
\text { "W" }\end{array}$ & $\begin{array}{c}\text { power turbine } \\
\text { "W" }\end{array}$ & rpm " N1 " & rpm "N2" & Torque "N.m" & $\begin{array}{c}\text { Power electric } \\
\text { "W" }\end{array}$ \\
\hline 3 & 74.81383088 & 32.16994728 & 30.56144991 & 119.4267516 & 358.2802548 & 0.809813947 & 27.50530492 \\
\hline 4 & 177.336488 & 76.25468984 & 72.44195535 & 159.2356688 & 477.7070064 & 1.439669239 & 65.19775981 \\
\hline 5 & 346.3603281 & 148.9349411 & 141.488194 & 199.044586 & 597.133758 & 2.249483186 & 127.3393746 \\
\hline 6 & 598.510647 & 257.3595782 & 244.4915993 & 238.8535032 & 716.5605096 & 3.239255788 & 220.0424394 \\
\hline 7 & 950.4127404 & 408.6774784 & 388.2436044 & 278.6624204 & 835.9872611 & 4.408987045 & 349.419244 \\
\hline 8 & 1418.691904 & 610.0375187 & 579.5356428 & 318.4713376 & 955.4140127 & 5.758676957 & 521.5820785 \\
\hline 9 & 2019.973434 & 868.5885765 & 825.1591476 & 358.2802548 & 1074.840764 & 7.288325523 & 742.6432329 \\
\hline 10 & 2770.882625 & 1191.479529 & 1131.905552 & 398.089172 & 1194.267516 & 8.14732745 & 1018.714997 \\
\hline 11 & 3688.044774 & 1585.859253 & 1506.56629 & 437.8980892 & 1313.694268 & 10.88749862 & 1355.909661 \\
\hline 12 & 4788.085176 & 2058.876626 & 1955.932794 & 477.7070064 & 1433.121019 & 12.95702315 & 1760.339515 \\
\hline 13 & 6087.629127 & 2617.680525 & 2486.796498 & 517.5159236 & 1552.547771 & 15.20650634 & 2238.116849 \\
\hline 14 & 7603.301923 & 3269.419827 & 3105.948836 & 557.3248408 & 1671.974522 & 17.63594818 & 2795.353952 \\
\hline 15 & 9351.728859 & 4021.24341 & 3820.181239 & 597.133758 & 1791.401274 & 20.24534868 & \multirow{11}{*}{$\begin{array}{l}\text { Power output } \\
\text { 3kw }\end{array}$} \\
\hline 16 & 11349.53523 & 4880.30015 & 4636.285142 & 636.9426752 & 1910.828025 & 23.03470783 & \\
\hline 17 & 13613.34634 & 5853.738925 & 5561.051979 & 676.7515924 & 2030.254777 & 26.00402563 & \\
\hline 18 & 16159.78747 & 6948.708612 & 6601.273181 & 716.5605096 & 2149.681529 & 29.15330209 & \\
\hline 19 & 19005.48392 & 8172.358088 & 7763.740183 & 756.3694268 & 2269.10828 & 32.48253721 & \\
\hline 20 & 22167.061 & 9531.83623 & 9055.244419 & 796.1783439 & 2388.535032 & 35.99173098 & \\
\hline 21 & 25661.14399 & 11034.29192 & 10482.57732 & 835.9872611 & 2507.961783 & 39.68088341 & \\
\hline 22 & 29504.35819 & 12686.87402 & 12052.53032 & 875.7961783 & 2627.388535 & 43.54999449 & \\
\hline 23 & 33713.3289 & 14496.73143 & 13771.89485 & 915.6050955 & 2746.815287 & 47.59906422 & \\
\hline 24 & 38304.68141 & 16471.01301 & 15647.46236 & 955.4140127 & 2866.242038 & 51.82809261 & \\
\hline 25 & 43295.04102 & 18616.86764 & 17686.02425 & 995.2229299 & 2985.66879 & 56.23707966 & \\
\hline
\end{tabular}


Table 5: Cash flow.

\begin{tabular}{|c|c|c|c|c|c|}
\hline $\begin{array}{l}\text { wind speed } \\
\text { " m/s " }\end{array}$ & $\begin{array}{c}\text { Power electric } \\
\text { "W" }\end{array}$ & $E_{(\mathrm{kWh})}$ & Income, \$ & Payback period in year & Profit, \$ \\
\hline 5 & 127.3393746 & 1059.71828 & 119.4 & & \\
\hline 6 & 220.0424394 & 1831.19318 & 206.33 & 28.45738788 & \\
\hline 7 & 349.419244 & 2907.86695 & 327.6 & 11.85401094 & 1698.8 \\
\hline 8 & 521.5820785 & 4340.60606 & 489.1 & 6.673060486 & 4922.5 \\
\hline 9 & 742.6432329 & 6180.27698 & 696.4 & 4.274316772 & 9068.2 \\
\hline 10 & 1018.714997 & 8477.74621 & 955.2 & 2.950003195 & 14245.6 \\
\hline 11 & 1355.909661 & 11283.8802 & 1271.4 & 2.140121938 & 20569.3 \\
\hline 12 & 1760.339515 & 14649.5454 & 1650.7 & 1.609989463 & 28153.9 \\
\hline 13 & 2238.116849 & 18625.6084 & 2098.7 & 1.245508453 & 37114.1 \\
\hline 14 & 2795.353952 & 23262.9356 & 2621.7 & 0.985341027 & 47564.4 \\
\hline
\end{tabular}

\section{Conclusion}

1. Jordan suffers from severe lack of energy resources, at the same time the energy consumption in Jordan is increasing yearly, which generates an economic overburden on the GDP.

2. The utilization of renewable energy (solar and wind) has become the foremost objective for the Jordanian Government in last few years to attain economic stability.

3. According to the Jordan Meteorological Department, the average wind speed in Jordan is $7 \mathrm{~m} / \mathrm{s}$, which is above the global average.

4. Using wind energy for street lighting becomes a valuable at a wind speed from $7 \mathrm{~m} / \mathrm{s}$, while cost recovery needs about 12 years. The benefits in this speed equalize 1700 US dollars.

\section{References}

[1] World Bank, Annual Report, 2015.

[2] The Hashemite Kingdom of Jordan The Higher Health Council "The National Strategy for Health Sector in Jordan 2015- 2019.

[3] Driving and Vehicles Licensing Department report, 2015. [4] Muhammad Ali Smiran, Mofleh Ali Smiran, "Syrian asylum and its impact on Jordan". International Conference "Humanitarian relief between Islam and international law and reality and aspirations.” Al- Albeit University, 17-18/06/2014.
[5] Nibal Zgheib" EBRD finances wind power plant in Jordan". The European Bank for Reconstruction and Development (EBRD), 31oct 2016, www.ebrd.com.

[6] N. Ramesh Babu, P. Arulmozhivarman " "Wind Energy Conversion Systems - A Technical Review ,“ Journal of Engineering Science and Technology, Vol. 8, No. 4 (2013) 493 - 507, School of Engineering, Taylor's University, 2013. [7] Decarboni.se, "Offshore wind market - 2012", European Wind Energy Association (EWEA). 1 July 2013. [8] Wagner, Hermann-Josef, Mathur, Jyotirmay "Introduction to Wind Energy Systems Basics", Technology and Operation, Second Edition, Springer Verlag Berlin Heidelberg,2013.

[9] Tony Burton et al., (Ed), "Wind Energy Handbook", John Wiley and Sons 200 page 65.

[10] Robert Gasch and Jochen Twele (Eds.), "Wind power plants. Fundamentals, design, construction and operation", Springer 2012.

[11] J. F. Manwell, J. G. McGowan and A. L. Rogers, "WIND ENERGY; Theory, Design and Application". United Kingdom, John Wiley \& Sons Ltd, 2009.

[12] Abdulkarim Abdulrazek, "Design and Power Characterization of A Small Wind Turbine Model In Partial Load Region",A thesis submitted in partial fulfillment of the requirements for the degree of Master of Science in Engineering Renewable Energy and Energy Efficiency for the MENA Region (REMENA), University of Kassel and Cairo University, Feb. 2012. 